University of Nebraska - Lincoln

DigitalCommons@University of Nebraska - Lincoln

2004

\title{
A Holocene pollen record of persistent droughts from Pyramid Lake, Nevada, USA
}

\author{
Scott A. Mensing \\ University of Nevada - Reno, smensing@unr.edu \\ Larry Benson \\ University of Colorado at Boulder, great.basin666@gmail.com \\ Michaele Kashgarian \\ Lawrence Livermore National Laboratory \\ Steve Lund \\ University of Southern California, slund@usc.edu
}

Follow this and additional works at: https://digitalcommons.unl.edu/usgsstaffpub

Part of the Geology Commons, Oceanography and Atmospheric Sciences and Meteorology Commons, Other Earth Sciences Commons, and the Other Environmental Sciences Commons

Mensing, Scott A.; Benson, Larry; Kashgarian, Michaele; and Lund, Steve, "A Holocene pollen record of persistent droughts from Pyramid Lake, Nevada, USA" (2004). USGS Staff -- Published Research. 783. https://digitalcommons.unl.edu/usgsstaffpub/783

This Article is brought to you for free and open access by the US Geological Survey at DigitalCommons@University of Nebraska - Lincoln. It has been accepted for inclusion in USGS Staff -- Published Research by an authorized administrator of DigitalCommons@University of Nebraska - Lincoln. 


\title{
A Holocene pollen record of persistent droughts from Pyramid Lake, Nevada, USA
}

\author{
Scott A. Mensing, ${ }^{\mathrm{a}, *}$ Larry V. Benson, ${ }^{\mathrm{b}}$ Michaele Kashgarian, ${ }^{\mathrm{c}}$ and Steve Lund ${ }^{\mathrm{d}}$ \\ ${ }^{a}$ Department of Geography, University of Nevada, Reno, NV 89557, USA \\ ${ }^{\mathrm{b}}$ U.S. Geological Survey, 3215 Marine Street, Boulder, CO, 80303, USA \\ ${ }^{\mathrm{c}}$ Lawrence Livermore National Laboratory, PO Box 808, Livermore, CA, 94550, USA \\ ${ }^{\mathrm{d}}$ Department of Earth Sciences, University of Southern California, Los Angeles, CA, 90089, USA
}

Received 19 August 2003

\begin{abstract}
Pollen and algae microfossils preserved in sediments from Pyramid Lake, Nevada, provide evidence for periods of persistent drought during the Holocene age. We analyzed one hundred nineteen 1-cm-thick samples for pollen and algae from a set of cores that span the past 7630 years. The early middle Holocene, 7600 to $6300 \mathrm{cal}$ yr B.P., was found to be the driest period, although it included one short but intense wet phase. We suggest that Lake Tahoe was below its rim for most of this period, greatly reducing the volume and depth of Pyramid Lake. Middle Holocene aridity eased between 5000 and 3500 cal yr B.P. and climate became variable with distinct wet and dry phases. Lake Tahoe probably spilled intermittently during this time. No core was recovered that represented the period between 3500 and 2600 cal yr B.P. The past 2500 years appear to have had recurrent persistent droughts. The timing and magnitude of droughts identified in the pollen record compares favorably with previously published $\delta^{18} \mathrm{O}$ data from Pyramid Lake. The timing of these droughts also agrees with the ages of submerged rooted stumps in the Eastern Sierra Nevada and woodrat midden data from central Nevada. Prolonged drought episodes appear to correspond with the timing of ice drift minima (solar maxima) identified from North Atlantic marine sediments, suggesting that changes in solar irradiance may be a possible mechanism influencing century-scale drought in the western Great Basin.

(C) 2004 University of Washington. All rights reserved.
\end{abstract}

Keywords: Pyramid Lake; Nevada; Great Basin; Pollen; Drought; Holocene; Climate change

\section{Introduction}

In western North America, periods of extended drought have significant effects on human populations. Evidence for recurrent droughts that may have lasted a century or longer comes from submerged stumps found in lakes along the eastern Sierra Nevada Range (Harding, 1935, 1965; Lindström, 1990; Stine, 1990). On shorter time scales, river flow reconstructed from tree-ring widths indicates periods of as many as 50 consecutive years when annual runoff of the Sacramento River remained below the 94-yr historical mean (Meko et al., 2001). In order to characterize the potential for future long-term droughts, high-resolution analyses of continuous proxy-climate records for the past few thousand years are needed. One source for this evidence is sediment

\footnotetext{
* Corresponding author. Fax: (775) 784-1058.

E-mail address: smensing@unr.edu (S.A. Mensing).
}

cores from lakes with high depositional rates. Benson et al. (2002) published a 7600-year record of $\delta^{18} \mathrm{O}$ of endogenic carbonates and magnetic susceptibility from Pyramid Lake, Nevada sediment cores that documented multidecadal and multicentennial droughts in the northern Sierra Nevada. In this paper, we present a high-resolution pollen record reconstructed from the same cores that documents vegetation change associated with persistent drought in the Holocene.

Pyramid Lake (1160 m surface elevation) is a closed-basin lake located in the rainshadow of the Sierra Nevada (Fig. 1). The primary tributary is the Truckee River, which has its headwaters on the eastern slope of the Sierra Nevada. Onethird of the Truckee's flow originates from Lake Tahoe. In the headwaters of the Truckee River, annual precipitation ranges from $1000 \mathrm{~mm}$ at Donner Lake to $805 \mathrm{~mm}$ at Lake Tahoe (National Climatic Data Center, 2003). At Pyramid Lake, annual precipitation at Sutcliffe, on the western shore, averages $200 \mathrm{~mm}$, whereas on the southeastern shore it averages 


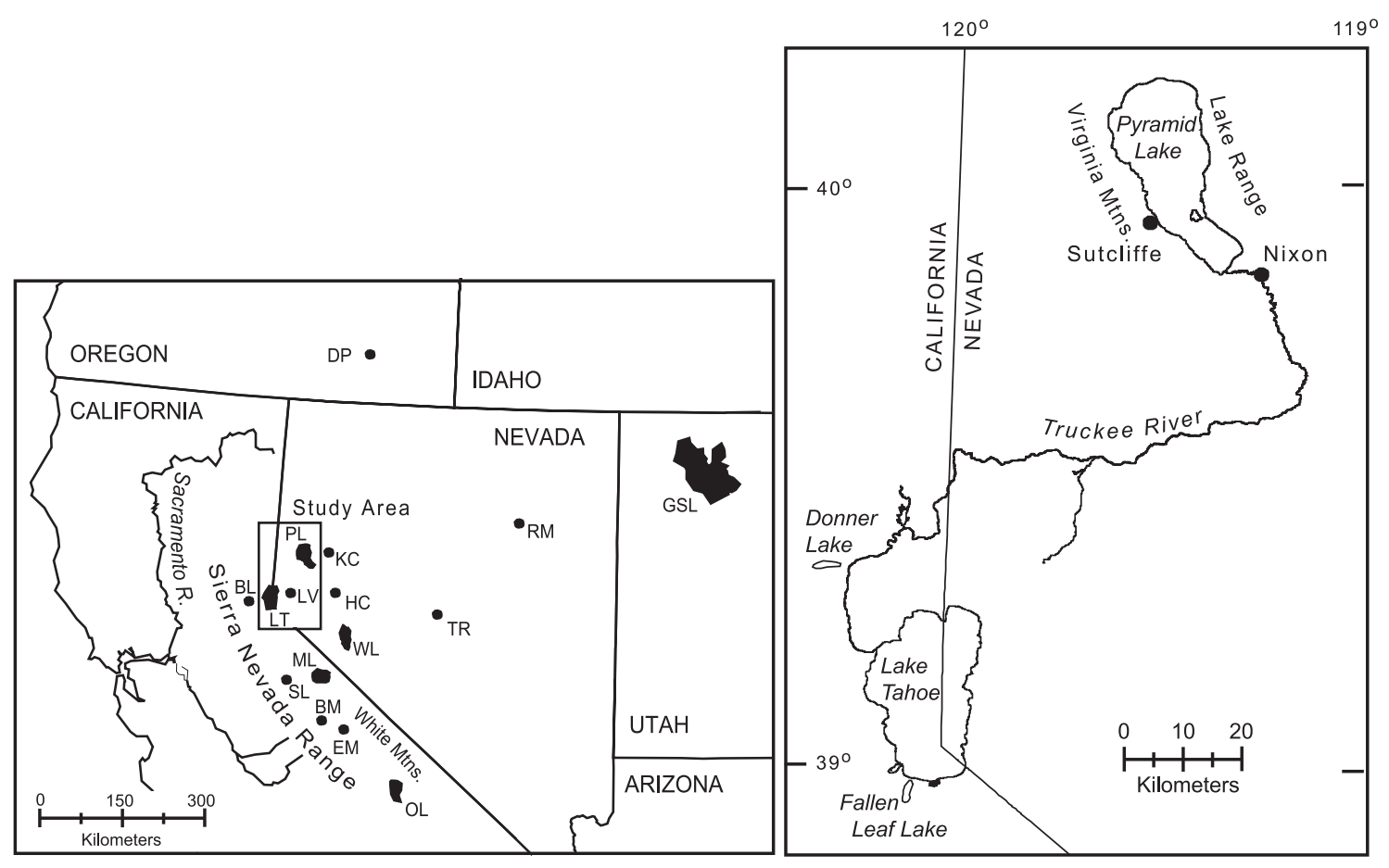

Fig. 1. Location maps of the study area and sites referred to in this paper. Abbreviations are: BL, Bunker Lake; BM, Balsam Meadow; DP, Diamond Pond; EM, Exchequer Meadow; GSL, Great Salt Lake; HC, Hidden Cave; KC, Krammer Cave; LT, Lake Tahoe; LV, Little Valley; ML, Mono Lake; OL, Owens Lake; PL, Pyramid Lake; RM, Ruby Marsh; SL, Swamp Lake; TR, Toiyabe Range, and WL, Walker Lake.

$160 \mathrm{~mm}$. Most precipitation in the Sierra Nevada falls during the winter months (Houghton et al., 1975).

Pyramid Lake lies along the ecotone between the shadscale and sagebrush vegetation zones (Billings, 1949). Shadscale typically dominates where annual precipitation is $<150 \mathrm{~mm}$, whereas sagebrush dominates where precipitation is $>180 \mathrm{~mm}$. Vegetation on the western, wetter side of Pyramid Lake is dominated by Artemisia tridentata (big sagebrush) and Ephedra nevadensis (Mormon tea). Also present are Purshia tridentata (bitterbrush), Tetradymia spp. (horsebrush), and Eriogonum spp. (buckwheat). Vegetation on the drier eastern shore is dominated by members of the Chenopodiaceae family, including Atriplex confertifolia (shadscale), Atriplex canescens (four-wing saltbush), Krashcheninnikovia lanata (winterfat), and Grayia spinosa (spiny hopsage), and the Sarcobataceae family, including Sarcobatus vermiculatus (greasewood),. The area surrounding Pyramid Lake is a treeless landscape, but scattered Juniperus osteosperma (Utah juniper) are present at higher elevations and an isolated pocket of Pinus jeffreyi (Jeffrey pine) can be found in the Virginia Mountains west of the lake. Salix spp. (willows) and Populus fremontii (cottonwood) are common along the Truckee River.

The nearest mixed conifer forest is approximately $50 \mathrm{~km}$ west in the Sierra Nevada, above $\sim 1650 \mathrm{~m}$ elevation, and is characterized by Pinus jeffreyi, $P$. ponderosa (ponderosa pine), Abies concolor (white fir), and Calocedrus decurrens (incense cedar). In the Lake Tahoe watershed, at elevations $>2300 \mathrm{~m}$, trees including Pinus contorta (lodgepole pine), $P$. monticola (western white pine), P. albicaulis (whitebark pine), Abies magnifica (red fir), and Tsuga mertensiana (mountain hemlock) dominate the landscape (Lanner, 1984). Understory shrubs include Quercus vaccinifolia (huckleberry oak), Ceanothus velutinus (tobacco brush), and Arctostaphylos spp. (manzanita). Montane riparian species include Alnus tenuifolia (mountain alder) and Betula occidentalis (water birch), in addition to Salix and Populus spp. Cercocarpus ledifolius (curlleaf mountain mahogany) grows on dry rocky slopes above the sagebrush zone between 1500 and $3000 \mathrm{~m}$ elevation.

\section{Methods}

Three cores were recovered from the deepest part of Pyramid Lake $(107 \mathrm{~m})$ in 1997 and 1998: a 0.59-m-long box core (PLB98-2) that recovered undisturbed surface sediments, a 5.35-m-long piston core (PLC97-1) and a 6.34-m-long piston core (PLC98-4). Age control is described in Benson et al. (2002). Accelerator mass spectrometry (AMS) radiocarbon dates were obtained on pine pollen (Mensing and Southon, 1999). The pollen dates were about 650 years older than the age model derived from paleomagnetic secular variation (PSV). Benson et al. (2002) found that Holocene-age sediments are missing from the margins of Pyramid Lake. Surface sediments from shallow water (ca. $7 \mathrm{~m}$ depth) date to $\sim 12,000$ cal yr B.P. The old radiocarbon dates on pollen indicate some rework- 
ing of Pleistocene-age pollen from the lake margins into the deep basin. We assume that $\sim 10 \%$ of the fine-sediment fraction in the deep basin has been reworked from the lake margins (Benson et al., 2002).

A total of one hundred nineteen 1-cm-thick samples were taken for pollen analysis; 14 from core PLB98-2, 56 from core PLC97-1, and 49 from core PLC98-4. Pollen preparation followed standard methods (Faegri and Iversen, 1985). A known quantity of Lycopodium spores was added to each sample to calculate pollen concentration (Stockmarr, 1971). Pollen was identified to the lowest possible taxonomic level using modern reference material and published pollen keys (Kapp et al., 2000; Moore and Webb, 1978). TCT (Taxodiaceae/Cupressaceae/Taxaceae) pollen was identified, but not used in the interpretation because it can represent two ecologically distinct taxa, Calocedrus decurrens, a montane species, or Juniperus osteosprema, a desert species. Algae also were identified, including Botryococcus and four species of Pediastrum (Jankovská and Komárek, 1982).

A minimum of 400 pollen grains were counted in each sample. Pollen percentages were calculated from the sum of terrestrial pollen and spores. Pollen accumulation rates were calculated by dividing the pollen concentration by the number of years represented by the sample. Algae were counted concurrently with pollen, and percentages were calculated from the sum of total algae. Pollen zonation was interpreted from a constrained single-link dendrogram created using a cluster analysis program modified from Birks and Gordon (1985), using the 14 most common taxa ( $>93 \%$ of the total pollen sum for each sample). Pollen spectra for each level were compared with every other level in the record using the squared-chord distance dissimilarity coefficient with a critical value of 0.12 (Overpeck et al., 1985) to test whether pollen assemblages within zones were distinct from pollen assemblages in different zones.

We used the ratio between Artemisia and Chenopodiaceae pollen as a proxy for lake-level change. Billings (1949) noted that species of the shadscale association (such as Atriplex confertifolia, Atriplex canescens, and Sarcobatus vermiculatus) typically occupy both moderately saline playa soils and xeric habitats. We hypothesize that during periods of drier climate when Pyramid Lake shrank exposing playa surfaces, individuals of the shadscale association would likely have dispersed into this habitat and increased in number on the landscape. Conversely, periods of wetter climate would have favored expansion of sagebrush and rising lake levels would have eliminated playa habitat. Thus, the ratio between percent Artemisia and Chenopodiaceae pollen (A/C ratio) should provide a proxy for lake-level change. We expect this signal to be lagged due to the time required for plant succession onto the playa. Previous studies by Mensing (2001), Wigand (1987), and Byrne et al. (1979) have all interpreted the $\mathrm{A} / \mathrm{C}$ ratio as a relative measure of available moisture in the Great Basin.
We tested the validity of the $\mathrm{A} / \mathrm{C}$ ratio on humaninduced lake-level decline in Pyramid Lake. Hydrologic modeling shows that during the past century, the surface elevation of Pyramid Lake would have dropped by only $3.5 \mathrm{~m}$ due to climate effects alone (Benson et al., 2002). In fact, the surface elevation of Pyramid Lake has dropped $>20 \mathrm{~m}$ as a result of water diversions from the Truckee River initiated in 1906. We analyzed pollen samples from the historic period (200-0 cal yr B.P.) at an average interval of $13 \mathrm{yr}$ to test whether the $\mathrm{A} / \mathrm{C}$ ratio responded as predicted to this human-induced lake-level decline or apparent drought.

\section{Results}

In this paper, results are discussed for several periods in the Holocene. The historic period (200-0 cal yr B.P.) is discussed first, and then prehistoric periods in the Holocene (7600-200 cal yr B.P.).

\section{The historic period (200-0 cal yr B.P.)}

Core PLB98-2 spans the period from 1860 to 1998 A.D., encompassing nearly the entire historical record. The pollen diagram can be divided into two zones, prediversion and postdiversion (Fig. 2). Pollen accumulation rates support the percentage data throughout the record. Pinus pollen averaged $50 \%$ between 1820 and 1865 A.D. and then decreased to $35 \%$ by 1895 A.D. Pinus remained relatively low $(\sim 35 \%)$ throughout the past $100 \mathrm{yr}$. The initial decrease could be due to either an actual decrease in pine pollen production in the Sierra Nevada at the end of the Little Ice Age, or removal of trees through clear-cutting in the upper watershed. Lumbering began in the mid-1850s A.D., boomed between 1860 and 1890 A.D., and slowed by the turn of the century (Wilson, 1992). Diversions appear to have affected riparian taxa such as Salix and Alnus, as these two pollen types decrease with the initiation of diversion and then increase in association with increased runoff between 1970 and 1990 A.D.

Chenopodiaceae pollen began to increase in relation to Artemisia pollen about 1950 A.D., approximately $40 \mathrm{yr}$ after diversion began. The lag in pollen production is consistent with our expectation of the time needed for plants to colonize the newly exposed surface and become mature. Percent Artemisia pollen decreased steadily after water diversion began. This signal is likely a response to the lake edge withdrawing further from the sagebrush zone. Although Artemisia is wind-pollinated, the pollen does not disperse far, typically traveling $<2 \mathrm{~km}$ from its point of origin (Solomon and Silkworth, 1986). The A/C ratio (Artemisia/Chenopodiaceae) decreased as predicted for lowered lake levels (Fig. 2), confirming that this ratio can be used as a proxy for lowered lake levels due to reduced river flows caused by extended drought in the 


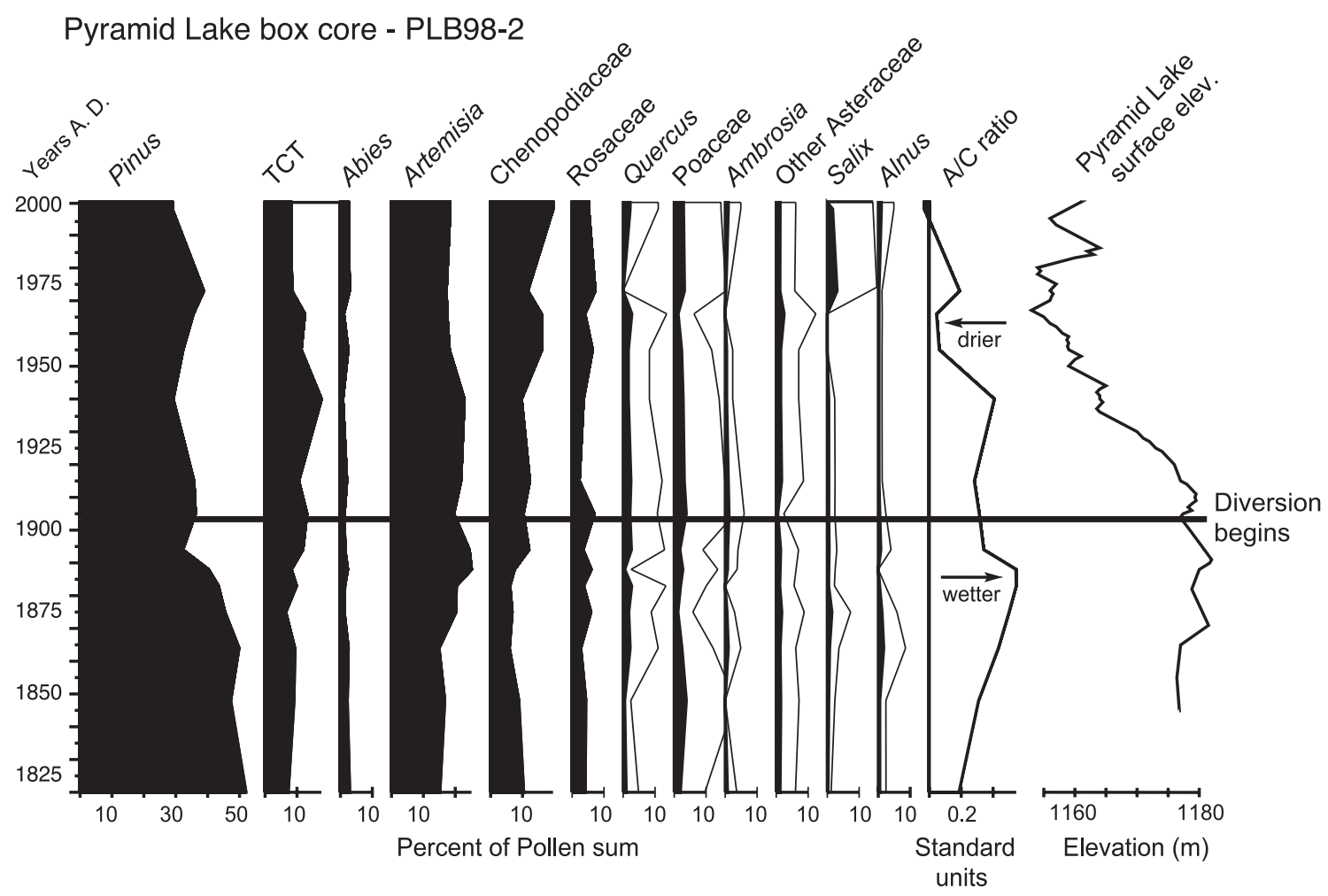

Fig. 2. Pollen percentage diagram for core PLB98-2 (box core). Lake level curve graphs the average annual surface elevation of Pyramid Lake. The ratio of Artemisia/Chenopodiaceae + Sarcobatus (A/C ratio) is calculated as $(\mathrm{a}-\mathrm{c}) /(\mathrm{a}+\mathrm{c})$, where "a" represents percent Artemisia and "c" represents percent Chenopodiaceae + Sarcobatus. Positive values represent increased Artemisia (wetter climate) and negative values represent increased Chenopodiaceae (drier climate). Lines to the right of filled curves are $5 \times$ exaggerations.

absence of water diversions. The $\mathrm{A} / \mathrm{C}$ ratio has approximately a 40- to 50-yr lag compared to the lake-level curve during the historic period. Since the $\mathrm{A} / \mathrm{C}$ ratio only records droughts of sufficient duration and intensity that lake level drops for periods of $>50 \mathrm{yr}$, we infer that minima in this ratio represent the most severe drought episodes.

The Holocene before the historic period (7530-200 cal yr B.P.)

Core PLC97-1 overlaps the box core, PLB98-2, and spans the period from 2640 to $\sim 130$ cal yr B.P. Core PLC98-4 spans the period from 7600 to 3430 cal yr B.P. There is a gap in the record between 3430 and $2740 \mathrm{cal} \mathrm{yr}$ B.P. (Fig. 3) (Benson et al., 2002). The sediment accumulation rate for PLC98-4 averaged $0.15 \mathrm{~cm}^{-1} \mathrm{yr}^{-1}$ and that for PLC97-1 averaged $0.21 \mathrm{~cm}^{-1} \mathrm{yr}^{-1}$. The interval between pollen samples in PLC98-4 averages $85 \mathrm{yr}$ (range 43 to $155 \mathrm{yr}$ ) and that in PLC97-1 averages $44 \mathrm{yr}$ (range 11 to 80 yr). Pollen analysis began in samples at $7530 \mathrm{cal}$ yr B.P.

Although the cluster analysis identified distinct groupings (Fig. 3), the squared-chord distance dissimilarity analysis showed that few of the pollen spectra within each zone were significantly different from the pollen spectra of other zones. This indicates that the magnitude of Holocene climate change was not sufficient to lead to local extinc- tions or the invasion of extralocal species. Pollen and algae stratigraphy for the four pollen zones is described in the following section.

\section{Interpretation and comparison with other records}

\section{0 to 6300 cal yr B.P. (zone 1A)}

The Pyramid Lake pollen data record high percentages of Chenopodiaceae in relation to Artemisia, high percentages of Ambrosia, and low percentages of Pinus pollen in zone $1 \mathrm{~A}$ between 7530 and $6300 \mathrm{cal}$ yr B.P. The A/C ratio (Fig. 3) suggests expansion of drought-tolerant species, such as Atriplex confertifolia, A. canescens, and Sarcobatus vermiculatus. The historic pollen record (Fig. 2) indicates that these species increase when lake-level drops and new shoreline is exposed. Ambrosia, a colonizer of open ground, probably also expanded in response to lower lake levels. Algae data also support the interpretation of a shallower lake. Pediastrum, predominates when lake level drops, as can be seen in the historic period, and is the dominant algae in zone 1A (Fig. 4).

Magnetic susceptibility data from core PLC98-4 are highest in zone 1A and support the interpretation of lower lake levels between 7600 and $6300 \mathrm{cal}$ yr B.P. (Fig. 4). Benson et al. (2002) stated that magnetic susceptibility 


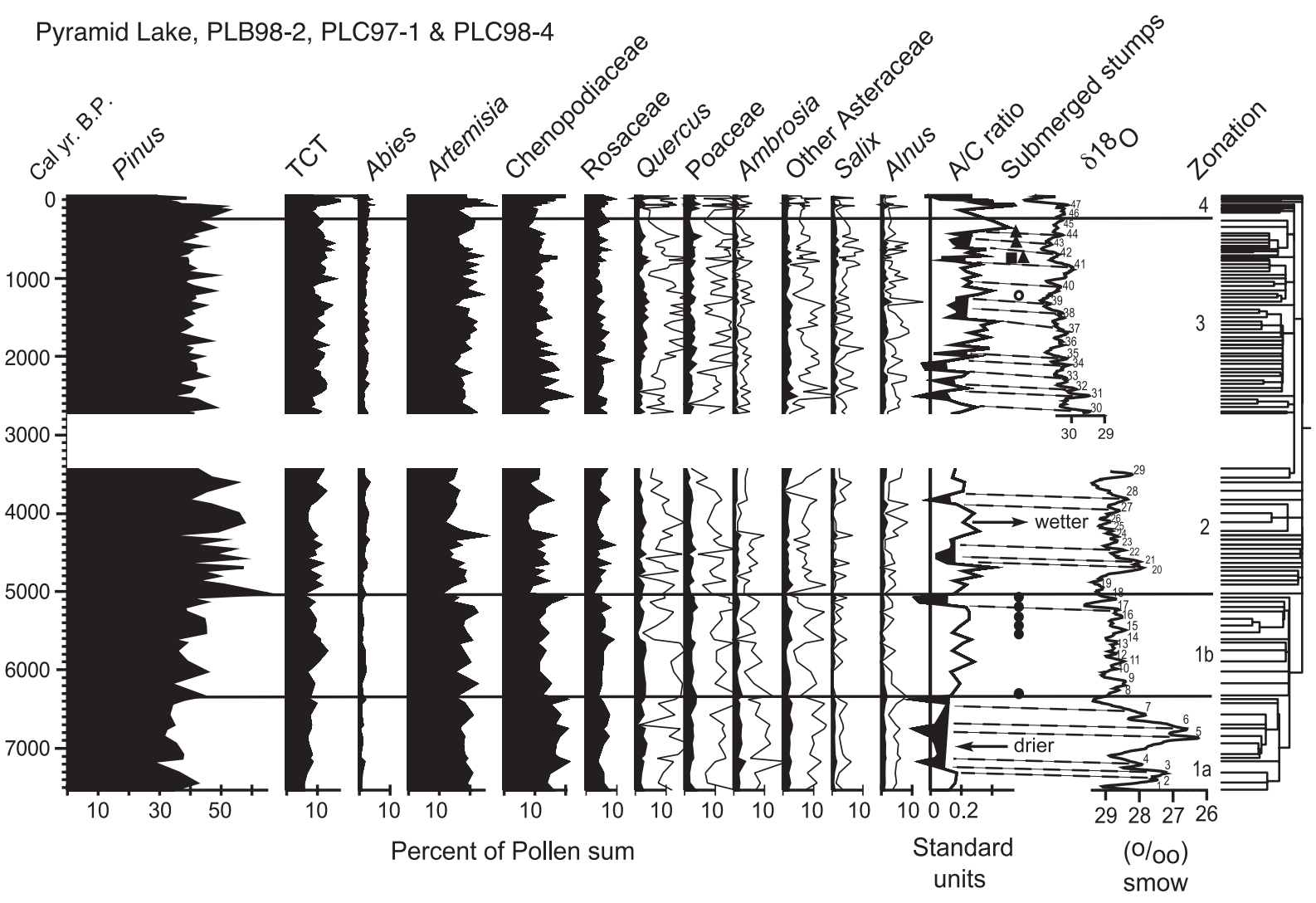

Fig. 3. Pollen percentage diagram of the most common pollen types for cores PLB98-2, PLC97-1, and PLC98-4. The ratio of Artemisia/Chenopodiaceae + Sarcobatus (A/C ratio) is calculated as $(\mathrm{a}-\mathrm{c}) /(\mathrm{a}+\mathrm{c})$, where "a" represents percent Artemisia and "c" represents percent Chenopodiaceae + Sarcobatus. Positive values represent increased Artemisia (wetter climate) and negative values represent increased Chenopodiaceae (drier climate). Dark fill in the A/C ratio represents periods interpreted to be extensive droughts. $\delta^{18} \mathrm{O}$ is a 40 -yr running average and wet-dry oscillations are numbered $1-47$ following Benson et al. (2002). Minimum values for $\delta^{18} \mathrm{O}$ indicate the termination of a wet period, beginning of a dry period. Dashed lines indicate the suggested correlation between inferred droughts in the $\delta^{18} \mathrm{O}$ and pollen records. Submerged stump radiocarbon ages are represented by geometric symbols: solid circles are from various locations in Lake Tahoe (Lindström, 1990); open circle is Rubicon Point, Lake Tahoe (Benson et al., 2002); square is Fallen Leaf Lake (Benson et al., 2002); and triangles are from Mono Lake (Stine, 1990; 1994). Lines to the right of filled curves are $5 \times$ exaggerations.

increased in the lake's depocenter as the lake shrank, i.e., more magnetite eroded from the basin margin reached the deepest part of the lake.

The $\delta^{18} \mathrm{O}$ record from Pyramid Lake supports the existence of periodic extended droughts. Benson et al. (2002) identified seven wet-dry oscillations between 7600 and 6300 cal yr B.P. (Fig 3). Minima in $\delta^{18} \mathrm{O}$ indicate the termination of wet periods and the beginning of droughts. Oscillations 3-7 indicate extended periods of declining lake levels, which correspond to negative values in the $\mathrm{A} / \mathrm{C}$ ratio. The pollen-sampling interval is not sufficient to identify a one-to-one correspondence between the two proxy records throughout this time period. At Mono Lake, a change to lower sedimentation and pollen accumulation rates at $7500 \mathrm{cal}$ yr B.P. has been interpreted as decreased stream discharge into the lake (Davis, 1999), an interpretation consistent with the Pyramid Lake record.

Submerged stumps in Lake Tahoe have been interpreted as evidence for century-long droughts (Harding, 1965; Lindström, 1990). Ring counts on submerged stumps indicate minimum ages of $100 \mathrm{yr}$. The deepest and oldest stump found is rooted $3.68 \mathrm{~m}$ below the natural sill of
Lake Tahoe with a death date of 6300 cal yr B.P. (Lindström, 1990). This date correlates with a strongly negative $\mathrm{A} / \mathrm{C}$ ratio and the ending of a significant drought indicated by the $\delta^{18} \mathrm{O}$ data (oscillation 7, Fig. 3).

Studies from lakes on the western Sierra Nevada Range have interpreted the pollen record to suggest that the early Holocene was warm and dry, and that cooler moister conditions began earlier than is seen in the Pyramid Lake record. Pollen evidence of a shift from Artemisia to Pinus dominance at Balsam Meadow has been interpreted as a shift from a dry climate to wetter climate by $\sim 7800 \mathrm{cal}$ yr B.P. Davis et al. (1985). Similar evidence from Exchequer Meadow, south of Balsam Meadow, has also been interpreted as a shift from dry to wetter climate by $\sim 7800 \mathrm{cal}$ yr B.P. (Davis and Moratto, 1988). At Swamp Lake in Yosemite National Park, north of Balsam Meadow (Fig. 1) a change from high percentages of Quercus pollen to increased Abies pollen at about $7350 \mathrm{cal}$ yr B.P. was interpreted as a shift at this time from warm dry climate to cooler and/or moister climate (Smith and Anderson, 1992). Still further north, evidence from Bunker Lake indicates a warm and dry climate persisting until $\sim 6800 \mathrm{cal}$ yr B.P. (Edlund, 1996). A possible explanation for these 


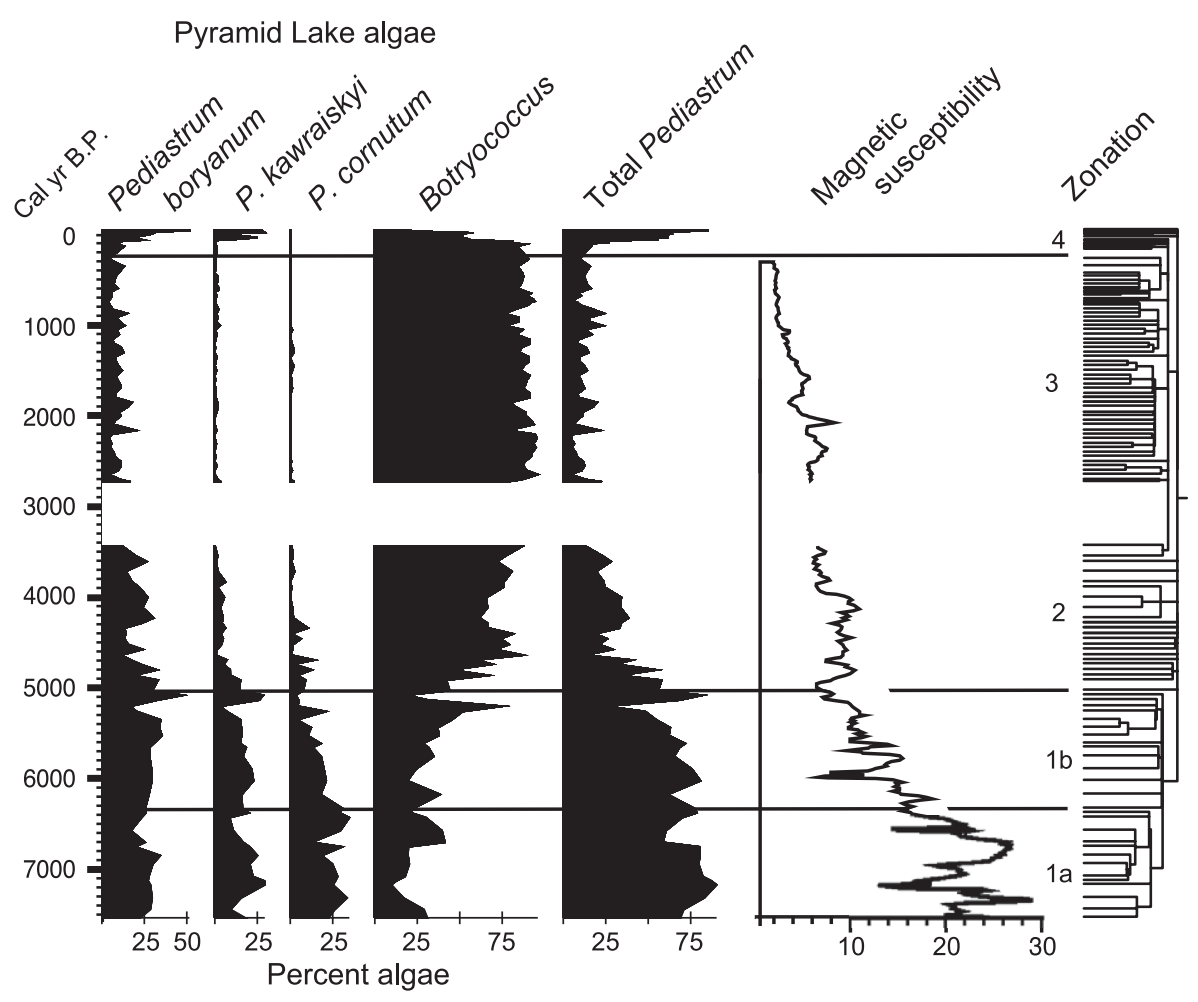

Fig. 4. Algae percent diagram and magnetic susceptibility. Magnetic susceptibility is represented as a 40-yr running average (Benson et al., 2002).

results is that the timing and duration of early and middle Holocene drought varied spatially, with warm dry climate persisting longer in the northern Sierra Nevada and the eastern side of the range.

Although the period from 7530 to $6300 \mathrm{cal} \mathrm{yr} \mathrm{B.P.} \mathrm{appears}$ to have been the driest in our record for the western Great Basin, it included a period of wetter climate. The strongest evidence for this variability comes from the $\delta^{18} \mathrm{O}$ record, which shows a substantial excursion towards lower values between 7000 to $6400 \mathrm{cal}$ yr B.P. (Fig. 3). High temperatures can produce low $\delta^{18} \mathrm{O}$ values due to decreased isotopic fractionation between carbonate and water, but the values seen here would have required a temperature increase of $19^{\circ} \mathrm{C}$. An increase of this magnitude would have completely changed the local plant species, and we see no evidence of this. An alternative explanation is that a pulse of fresh water entered the shallow, hydrologically closed lake. Benson et al. (2002) suggest that a short but possibly intense wet phase raised the lake level between 7000 and $6800 \mathrm{cal}$ yr B.P. This short but significant wet phase also is recorded by a higher lake-level in the Great Salt Lake (Madsen et al., 2001). Between 6750 and $6700 \mathrm{cal}$ yr B.P., percent Botryococcus doubled from $20 \%$ to $41 \%$, possibly in response to an influx of fresh water (Fig. 4). The A/C ratio varies but does not indicate a shift to wetter climate. One possible explanation for this is that if the lake had a much smaller surface area, the freshwater input could have a significant effect on $\delta^{18} \mathrm{O}$, yet the lake may have still been well below modern levels with a large expanse of saltbush species around the shoreline.
6300 to 5000 cal yr B.P. (zone 1B)

Pollen and algae indicate a shift towards wetter climate and increased lake level beginning $\sim 6300 \mathrm{cal} \mathrm{yr} \mathrm{B.P.} \mathrm{The}$ $\mathrm{A} / \mathrm{C}$ ratio increased indicating an increase in sagebrush relative to saltbush species. Mean percent Ambrosia pollen decreased from $2 \%$ in zone $1 \mathrm{~A}$ to $1 \%$ in zone $1 \mathrm{~B}$ and Pinus increased from $35 \%$ to $40 \%$ (Fig. 3). Percent Pediastrum remained high relative to Botryococcus, but the mean declined from $79 \%$ Pediastrum in zone $1 \mathrm{~A}$ to $64 \%$ in zone 1B (Fig. 4). Between 5200 and $5000 \mathrm{cal} \mathrm{yr} \mathrm{B.P.} \mathrm{there}$ is a sharp decline in the $\mathrm{A} / \mathrm{C}$ ratio coinciding with a sharp increase in Pediastrum from $25 \%$ to $82 \%$. This change correlates with an inferred drought in the $\delta^{18} \mathrm{O}$ data (oscillation 17, Fig. 3).

Western Sierra Nevada pollen records all agree that climate had become wetter and/or cooler by $6300 \mathrm{cal} \mathrm{yr}$ B.P. (Davis et al., 1985; Davis and Moratto, 1988; Smith and Anderson, 1992; Edlund, 1996).

A set of Lake Tahoe stumps are rooted between 0 and 1.3 $\mathrm{m}$ below the natural sill with death dates ranging from 5600 to $5000 \mathrm{cal}$ yr B.P. (Lindström, 1990). The pollen evidence indicates a drought occurred between 5200 and $5000 \mathrm{cal} \mathrm{yr}$ B.P. (Fig. 3). It is unclear why the pollen data do not indicate an extended dry period between 5600 and 5200 cal yr B.P., but both the pollen and $\delta^{18} \mathrm{O}$ data suggest that the most severe drought occurred between 5200 and 5000 cal yr B.P. This drought is not identified in western Sierra Nevada pollen records (Davis et al., 1985; Davis and 
Moratto, 1988; Smith and Anderson, 1992) or the Mono Lake pollen record (Davis, 1999) but the sampling resolution of these studies (ca. 250-500 yr between samples) precludes identification of events at the centennial scale.

5000 to 3400 cal yr B.P. (zone 2)

Beginning at 5000 cal yr B.P. there is an increase in montane tree pollen (Fig. 3). Pinus increases to its highest average $(48 \%)$ in zone 2 , but is variable, ranging from 30 to $65 \%$. Average percent Abies increases from 1 to $2 \%$. Both Chenopodiaceae and Artemisia decline slightly, but like Pinus, are highly variable throughout the zone. This variability is reflected in the $\mathrm{A} / \mathrm{C}$ ratio. Botryococcus becomes the dominant algae in zone 2 (Fig. 4).

There is evidence for a wetter climate across the northern Great Basin beginning about 5000 cal yr B.P. We suggest that it was highly variable, with distinct wet and dry phases. The Pyramid Lake pollen record shows an initial wet phase from 5000 to 4700 cal yr B.P (Fig. 3). The increase in Pinus and Abies pollen is probably associated with increased fluvial transport. Abies is a large, poorly dispersed pollen type and probably only reaches Pyramid Lake via the Truckee River. The date 5000 cal yr B.P. marks the final death date of rooted stumps in Lake Tahoe, suggesting that lake level rose, drowned trees, and increased flow in the Truckee River. There also is a shift in algae from Pediastrum to Botryococcus, indicating that Pyramid Lake deepened. Taken as a whole, the data indicate that middle Holocene aridity ended about 5000 cal yr B.P.

Grayson (1993) notes that after 5000 cal yr B.P. archeological sites increase in abundance in the Great Basin, and at Diamond Pond, Oregon, Wigand (1987) found indications of a high water table beginning $\sim 5000$ cal yr B.P. At Little Valley, $20 \mathrm{~km}$ east of Lake Tahoe, Abies and Alnus pollen increase, indicating a wetter climate (Wigand and Rhode, 2002). In central Nevada, the pollen record from Ruby Marsh indicates a decline in shadscale (Chenopodiaceae) and deeper water after 5000 cal yr B.P. (Thompson, 1992). In Utah, the return of cooler and wetter conditions resulted in freshening of the Great Salt Lake, allowing the survival of the moderately saline-tolerant Utah chub and increased diversity in waterfowl (Madsen et al., 2001). In the White Mountains, treeline advanced upslope beginning about 5000 cal yr B.P. (LaMarche, 1973). That study found an unusually large number of trees dating to the period between 4750 and 4550 cal yr B.P. and interpreted this to indicate unusual summer warmth and relatively high amounts of precipitation.

This initial wet phase beginning at $\sim 5000$ cal yr B.P. was followed by a period of drier climate at Pyramid Lake from 4700 to 4300 cal yr B.P. indicated by lower values in the $\mathrm{A} / \mathrm{C}$ ratio and higher values in the $\delta^{18} \mathrm{O}$ record (oscillations 20-22). This is followed by a wetter period from 4300 to 3900 cal yr B.P. This wet period is identified in several Great Basin records. Paleoecological and archeo- logical evidence from Hidden Cave (Wigand and Mehringer, 1985) and Kramer Cave (Hattori, 1982) indicate reoccupation of these sites by 4200 cal yr B.P., and collection of wetland plants associated with expansion of the nearby marshes. At Diamond Pond, abundant aquatic plants indicate deep water and an extensive marsh system between 4100 and 3900 cal yr B.P. (Wigand, 1987).

The Pyramid Lake pollen and $\delta^{18} \mathrm{O}$ records indicate a short dry phase between 3900 and 3800 cal yr B.P. followed by a wet phase between 3800 and 3400 cal yr B.P. Stine (1990) found evidence suggesting a highstand of Mono Lake at $3770 \mathrm{cal}$ yr B.P. The pollen record from Mono Lake has the highest percentage of Pinus at this time, supporting the interpretation of a wetter climate (Davis, 1999). Between $\sim 4000$ and 3300 cal yr B.P., the upper treeline on Sheep Mountain in the White Mountains lowered $100 \mathrm{~m}$, probably associated with cooler summer temperatures (LaMarche, 1973). Madsen et al. (2001) note that the Great Salt Lake expanded to reach the Nevada/Utah border and refer to this major wet event as the most dramatic climate change in the Holocene. Pollen and macrofossil evidence from Diamond Pond indicate expansion of juniper woodland into sagebrush and shadscale zones, supporting the interpretation of cooler, wetter conditions dominated by increased winter precipitation (Wigand, 1987). In southern Oregon, cool and wet conditions persisted until $\sim 2000$ cal yr B.P., whereas, in central Nevada, they ended by 2500 cal yr B.P. Pollen records in the western Sierra Nevada generally indicate intensified cooling after about 3900 cal yr B.P. (Smith and Anderson, 1992).

Benson et al. (2002) found that Pyramid Lake $\delta^{18} \mathrm{O}$ increased from 3430 cal yr B.P. to 2740 cal yr B.P. (Fig. 3). They interpreted the increase as evidence that Pyramid Lake had remained isotopically closed between 5000 and $3430 \mathrm{cal}$ yr B.P. and that continued dry Sierran climate prevented Lake Tahoe from spilling throughout most of this period. The pollen evidence suggests that Lake Tahoe probably did spill intermittently between 5000 and 3430 cal yr B.P., but the climate was not wet enough for Lake Tahoe to spill continuously during this period. After 3430 cal yr B.P., increased precipitation probably caused Lake Tahoe to fill, raising the level of Pyramid Lake. Since about 3430 cal yr B.P., Lake Tahoe has probably overflowed most years, maintaining a deeper Pyramid Lake than that which existed during the middle Holocene. Tausch et al. (2004) reviewed pollen, woodrat midden, treeline, and lake-level evidence for the Great Basin and identified the period from 3500 to $2600 \mathrm{cal}$ yr B.P. as much cooler and wetter than any time during the previous 4000 yr. Unfortunately, most of this period is absent from the core record described in this study.

\section{0 to 200 cal yr B.P. (zone 3)}

Artemisia averages $18 \%$ and Pinus averages $40 \%$ in zone 3 (Fig. 3). Chenopodiaceae pollen averages 12\% throughout zone 3 , but has peaks between 16 and $21 \%$ between 2500 
and 2000 cal yr B.P. (Fig. 3). The A/C ratio includes a series of minima associated with peak values of Chenopodiaceae. We infer these minima to represent regional droughts when Pyramid Lake was low.

The last $2500 \mathrm{yrs}$ are notable for the recurrence of persistent droughts. Stine (1994) suggested that submerged stumps at Mono Lake provided evidence for century long droughts in the western Great Basin. The Pyramid Lake pollen record supports this conclusion and provides evidence for a series of extended droughts in the western Great Basin (LaMarche, 1973; Meko et al., 2001; Miller et al., 2001).

The $\delta^{18} \mathrm{O}$ record identifies 18 wet/dry oscillations $(30-47)$ over the past $2750 \mathrm{yr}$ (Fig. 3). Multiple processes influence the amplitude of $\delta^{18} \mathrm{O}$ oscillations, such that the absolute intensity of wet and dry periods is difficult to interpret; however the timing and duration of events can be accurately characterized (Benson et al., 2002). Twelve minima in the A/ $\mathrm{C}$ ratio correlate with dry oscillations in the $\delta^{18} \mathrm{O}$ lagged $40-$ 65 yr. A 65 -yr lag is 15-25 years longer than the lag identified from the historic period in the box core, but the sampling interval in core PLC97-1 averages $44 \mathrm{yr}$, precluding our ability to identify a shorter-term lag. In most cases, the beginning of droughts in the $\delta^{18} \mathrm{O}$ record (shift from lower to higher $\delta^{18} \mathrm{O}$ values) corresponds to lower $\mathrm{A} / \mathrm{C}$ values (shift to more Chenopodiaceae pollen) with an average lag in the pollen record of $50 \mathrm{yr}$.

Between 2500 and 2000 cal yr B.P., the $\mathrm{A} / \mathrm{C}$ ratio repeatedly achieves minima comparable to those recorded during the middle Holocene and equal to those in the historic period when Pyramid Lake has fallen 20 m below the historic high. These minima correspond with oscillations 30 to 35 in the $\delta^{18} \mathrm{O}$ record (Fig. 3) and support other data that indicate an extended dry period between 2500 and 2000 cal yr B.P. (Tausch et al., 2004). Woodrat middens near streams in the Toiyabe Range in central Nevada have low diversity between 2500 and 2000 cal yr B.P., indicating local extinction of riparian species during a severe drought. Geomorphic evidence from the same region interprets active deposition on alluvial fans associated with loss of hillslope vegetation (Miller et al., 2001). Wet sedge meadows in the Toiyabe were converted to dry grassy flats about $2100 \mathrm{cal} \mathrm{yr}$ B.P. (Tausch et al., 2004), and between 2500 and $2400 \mathrm{cal} \mathrm{yr}$ B.P. treeline lowered by $\sim 30 \mathrm{~m}$ on Campito Mountain in the White Mountains. LaMarche (1973) speculated that this change was in response to drier conditions. A sediment core from Mono Lake contains sand layers and increased Artemisia pollen at $2400 \mathrm{cal} \mathrm{yr} \mathrm{B.P,} \mathrm{indicating} \mathrm{lowered} \mathrm{lake} \mathrm{level}$ and a dry climate (Davis, 1999). Sedimentary evidence of subaerially desiccated clays and stream gravels have been interpreted as a Mono Lake low stand with a provisional date of $1800 \mathrm{cal}$ yr B.P. (Stine, 1990).

Three more droughts are inferred from the $\mathrm{A} / \mathrm{C}$ ratio, from 1500 to 1250,800 to 725 , and 600 to 450 cal yr B.P. (Fig. 3). The end date of each drought corresponds with the dates of submerged rooted stumps recovered from lakes in the eastern Sierra Nevada and western Great Basin. All evidence cited here represents dates on outer rings (death dates) from rooted stumps and trees. The drought between 1500 and $1250 \mathrm{cal} \mathrm{yr}$ B.P. corresponds with a date of $1240 \pm 40{ }^{14} \mathrm{C}$ yr B.P. ( 1200 cal yr B.P.) on a stump recovered from Rubicon Point, Lake Tahoe (Benson et al., 2002). The drought between 800 and $725 \mathrm{cal}$ yr B.P. corresponds with a date of $850 \pm 40{ }^{14} \mathrm{C}$ yr B.P. $(\sim 750 \mathrm{cal}$ yr B.P. $)$ on several submerged trees in Fallen Leaf Lake (Benson et al., 2002), and a series of stumps from Mono Lake that date the termination of the Simis Ranch low stand at $\sim 700 \mathrm{cal}$ yr B.P. (Stine, 1990). The drought between 600 and $450 \mathrm{cal}$ yr B.P. corresponds with a second series of Mono Lake stumps which indicate the termination of the 10-mile Road low stand $\sim 550$ cal yr B.P. (Stine, 1990).

A stream flow reconstruction for the Sacramento River (Fig. 1) developed from tree-rings, indicated that in the past $1100 \mathrm{yr}$, the period between 1350 and 1400 A.D. (600 to 550 cal yr B.P.) was the driest 50-yr period and between 1140 and 1160 A.D. $(\sim 800-780$ cal yr B.P. $)$ was the driest $20-\mathrm{yr}$ period (Meko et al., 2001). At Walker Lake, a large closedbasin lake in the western Great Basin comparable to Pyramid Lake, the $\delta^{18} \mathrm{O}$ data indicate generally drier conditions during the period of 950 to 590 cal yr B.P. with century-scale drought events terminating at 750 and $590 \mathrm{cal} \mathrm{yr} \mathrm{B.P.} \mathrm{(Yuan} \mathrm{et} \mathrm{al.,}$ 2004). Thus, the timing of major droughts identified in the

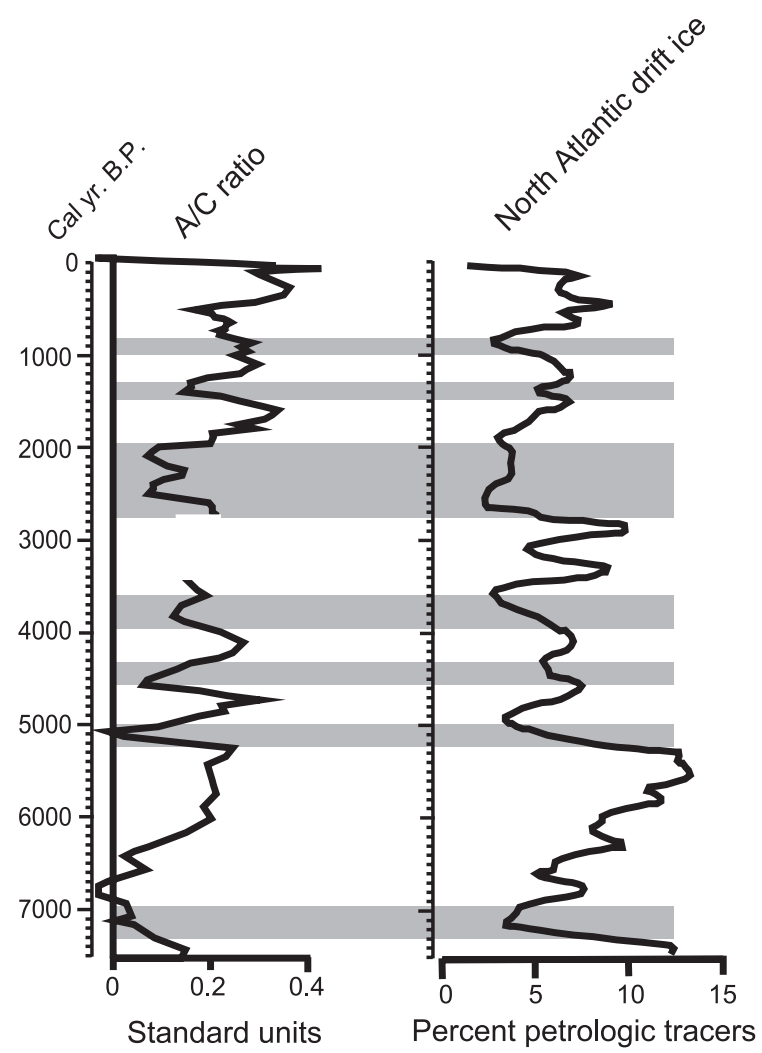

Fig. 5. Pyramid Lake $\mathrm{A} / \mathrm{C}$ ratio and North Atlantic drift ice (Bond et al., 2001) records. The $\mathrm{A} / \mathrm{C}$ ratio is represented as a $200-\mathrm{yr}$ running average. Gray bands indicate periods of possible correlation between inferred droughts in the pollen record and periods of reduced ice rafted debris. 
Pyramid Lake pollen data agrees with other regional records of drought reconstructed from lake-level data, tree-ring data, and $\delta^{18} \mathrm{O}$ data.

\section{Comparison with the North Atlantic ice drift record}

Bond et al. (2001) reconstructed a record of drift ice in the North Atlantic from petrologic tracers found in marine sediment cores. They correlated tracers with the production rates of two cosmogenic nuclides related to solar activity, ${ }^{14} \mathrm{C}$ and ${ }^{10} \mathrm{Be}$, and found that over the past $12,000 \mathrm{yr}$, decreases in drift ice abundance corresponded to increased solar output. General circulation models have shown that small changes in solar forcing, such as those during the Maunder Minimum, have resulted in large regional temperature changes across the Northern Hemisphere continents (Shindell et al., 2001). We compared the pollen record of droughts from Pyramid Lake with the stacked petrologic record of North Atlantic drift ice (Fig. 5). In the past 7600 $\mathrm{yr}$, nearly every occurrence of a shift from ice maxima (reduced solar output) to ice minima (increased solar output) corresponded with a period of prolonged drought in the Pyramid Lake record.

Reduced solar irradiance has been correlated with droughts in the Yucatan Peninsula (Hoddel et al., 2001) and lake level changes in equatorial Africa, and drift-ice cycles correspond with temperature cycles in the Sargasso Sea (Bond et al., 2001). Solar forcing has been suggested as a possible mechanism for century-scale droughts in the northern Great Plains of North America (Yu and Ito, 1999). The correlation between North Atlantic drift ice and the Pyramid Lake pollen record suggests that increased solar irradiance is a possible mechanism to induce extended drought in the western Great Basin of North America, although the link between solar irradiance and climate change is still poorly understood.

\section{Conclusion}

The Pyramid Lake pollen record presents a complex picture of Holocene climate change. The early middle Holocene (7600-6300 cal yr B.P.) was the driest period in the last $7600 \mathrm{yr}$, but at least one intense wet period interrupted the general aridity. By 5000 cal yr B.P., maximum aridity ended and a period of variable climate followed, including clearly identifiable wet and dry phases. Sometime after 3430 but before 2750 cal yr B.P., climate became cool and wet, and Lake Tahoe began to spill continuously, raising the water-level elevation of Pyramid Lake. The past 2500 yr have been marked by recurring persistent droughts. The longest of these droughts occurred between 2500 and 2000 cal yr B.P. Extended droughts occurred between 1500 and 1250, 800 and 725, and 600 and $450 \mathrm{cal}$ yr B.P. These droughts correlate with dry periods inferred from ages of submerged stumps and recon- structed stream-flow records. Century-scale droughts that occurred during the past $5000 \mathrm{yr}$ may be related to changes in solar irradiance.

\section{Acknowledgments}

We thank Robin Tausch, Kelly Redmond, and Peter Wigand for helpful discussion on Great Basin climate history and reviews of an earlier version of this manuscript. The final version of this manuscript was improved by comments from Emi Ito, Marith Reheis, and two anonymous reviewers. Alan Hayvaert and Bob Richards collected the box core. Gary Johnson provided spatial data for Fig. 1. The Pyramid Lake Paiute Tribe generously provided access to Pyramid Lake. The senior author's work was supported by a sabbatical leave grant from the University of Nevada, Reno.

\section{References}

Benson, L., Kashgarian, M., Rye, R., Lund, S., Paillet, F., Smoot, J., Kester, C., Mensing, S., Meko, D., Lindstrom, S., 2002. Holocene multidecadal and multicentennial droughts affecting Northern California and Nevada. Quaternary Science Reviews 21, 659-682.

Billings, W., 1949. The shadscale vegetation zone of Nevada and Eastern California in relation to climate and soils. The American Midland Naturalist 42, 87-109.

Birks, H.J.B., Gordon, A.D., 1985. Numerical Methods in Quaternary Pollen Analysis. Academic Press, London.

Bond, G., Kromer, B., Beer, J., Muscheler, R., Evans, M., Showers, W., Hoffmann, S., Lotti-Bond, R., Hajdas, I., Bonani, G., 2001. Persistent solar influence on North Atlantic climate during the Holocene. Science 294, 2130-2136.

Byrne, R., Busby, C., Heizer, R.F., 1979. The Altithermal revisited: Pollen evidence from the Leonard Rockshelter. Journal of California and Great Basin Anthropology 1, 280-294.

Davis, O.K., 1999. Pollen analysis of a late-glacial and Holocene sediment core from Mono Lake, Mono County, California. Quaternary Research $52,243-249$.

Davis, O.K., Moratto, M.J., 1988. Evidence for a warm dry early Holocene in the western Sierra Nevada of California: Pollen and plant macrofossil analysis of Dinkey and Exchequer Meadows. Madroño 35 (2), 132-149.

Davis, O.K., Anderson, R.S., Fall, P.L., O’Rourke, M.K., Thompson, R.S., 1985. Palynological evidence for early Holocene aridity in the southern Sierra Nevada, California. Quaternary Research 24, 322-332.

Edlund, E.G., 1996. Late Quaternary Environmental History of Montane Forests of the Sierra Nevada, California. Ph.D. dissertation, University of California, Berkeley.

Faegri, K., Iversen, J., 1985. Textbook of Pollen Analysis, fourth ed. Hafner Press, New York.

Grayson, D.K., 1993. The Desert's Past: A Natural Prehistory of the Great Basin Smithsonian Institution Press, Washington, DC.

Harding, S.T., 1935. Changes in lake levels in Great Basin area. Civil Engineering 5, 87-90.

Harding, S.T., 1965. Recent Variations in the Water Supply of the Great Basin. Archives Series Report 16, University of California, Berkeley.

Hattori, E., 1982. The Archaeology of Falcon Hill, Winnemucca Lake, Washoe County, Nevada. Nevada State Museum Anthropological Papers 18. 
Hoddel, D.A., Brenner, M., Curtis, J.H., Guilderson, T., 2001. Solar forcing of drought frequency in the Maya lowlands. Science 292, $1367-1370$.

Houghton, J.G., Sakamoto, C.M., Gifford, R.O., 1975. Nevada's Weather and Climate. University of Nevada, Reno.

Jankovská, V., Komárek, J., 1982. Das vorkommen einiger chlorokokkalalgen in bohmischen spatglazial und postglazial. Folia Geobotanica et Phytotaxonomica, Praha 17, 165-195.

Kapp, R.O., Davis, O.K., King, J.E., 2000. Ronald O. Kapp's Pollen and Spores, second ed. American Association of Stratigraphic Palynologists, College Station, TX.

Lanner, R., 1984. Trees of the Great Basin. University of Nevada Press, Reno, NV.

LaMarche Jr., V., 1973. Holocene climatic variations inferred from treeline fluctuations in the White Mountains, California. Quaternary Research 3, $632-660$

Lindström, S., 1990. Submerged tree stumps as indicators of middle Holocene aridity in the Lake Tahoe Basin. Journal of California and Great Basin Anthropology 12, 146-157.

Madsen, D., Rhode, D., Grayson, D., Broughton, J., Livingston, S., Hunt, J., Quade, J., Schmitt, D., Shaver III, M., 2001. Late Quaternary environmental change in the Bonneville Basin Western USA. Palaeogeography, Palaeoclimatology, Palaeoecology 167, 243-271.

Meko, D., Therrel, M., Baisan, C., Hughes, M., 2001. Sacramento River flow reconstructed to A.D. 869 from tree rings. Journal of the American Water Resources Association 37, 1029-1039.

Mensing, S., 2001. Late-Glacial and early Holocene vegetation and climate change near Owens Lake, eastern California. Quaternary Research 55, 57-65.

Mensing, S.A., Southon, J.R., 1999. A simple method to separate pollen for AMS radiocarbon dating and its application to lacustrine and marine sediments. Radiocarbon 41, 1-8.

Miller, J., Germanoski, D., Waltman, K., Tausch, R., Chambers, J., 2001. Influence of late Holocene hillslope processes and landforms on modern channel dynamics in upland watersheds of central Nevada. Geomorphology 38, 373-391.

Moore, P.D., Webb, J.A., 1978. An Illustrated Guide to Pollen Analysis. Wiley, New York.

National Climatic Data Center, 2003. Northern California Climate Summaries, Station 042467 (Donner Memorial State Park, CA) and Station 048758 (Tahoe, California), available at: http://www.wrcc.dri.edu/ summary/climsmnca.html.

Overpeck, J.T. , Webb III, T., Prentice, I.C., 1985. Quantitative interpreta- tion of fossil pollen spectra: dissimilarity coefficients and the method of modern analogs. Quaternary Research 23, 87-108.

Shindell, D.T., Scmidt, G.A., Mann, M.E., Rind, D., Waple, A., 2001. Solar forcing of regional climate change during the Maunder Minimum. Science 294, 2149-2152.

Smith, S., Anderson, R.S., 1992. Late Wisconsin paleoecologic record from Swamp Lake, Yosemite National Park. Quaternary Research $38,91-102$.

Solomon, A.M., Silkworth, A.B., 1986. Spatial patterns of atmospheric pollen transport in a montane region. Quaternary Research 25, 150-162.

Stine, S., 1990. Late Holocene fluctuations of Mono Lake, eastern California. Paleogeography, Palaeoclimatology and Palaeoecology 78, $333-381$.

Stine, S., 1994. Extreme and persistent drought in California and Patagonia during mediaeval time. Nature 369, 546-549.

Stockmarr, J., 1971. Tablets with spores used in absolute pollen analysis. Pollen et Spores 13, 615-621.

Tausch, R., Nowak, C., Mensing, S., 2004. Climate change and associated vegetation dynamics during the Holocene: the paleoecological record. In: Chambers, Jeanne C., Miller, Jerry R. (Eds.), Great Basin Riparian Ecosystems: Ecology, Management and Restoration. Island Press, Covelo, CA, pp. 24-48.

Thompson, R.S., 1992. Late Quaternary Environments in Ruby Valley, Nevada. Quaternary Research 37, 1-15.

Wigand, P.E., 1987. Diamond Pond, Harney County, Oregon: vegetation history and water table in the Eastern Oregon desert. Great Basin Naturalist 47, 427-458.

Wigand, P.E., Mehringer Jr., P.J., 1985. Pollen and seed analyses. In: Thomas, D.H. (Ed.), The Archaeology of Hidden Cave. Anthropological Papers of the American Museum of Natural History, vol. 61. 108124 (Chap. 9).

Wigand, P.E., Rhode, D., 2002. Great basin vegetation history and aquatic systems: the last 150,000 years. In: Hershler, R., Madsen, D.B., Currey, D.R. (Eds.), Great Basin Aquatic Systems History. Smithsonian Contributions to the Earth Sciences, vol. 33. Smithsonian Institution Press, Washington, D.C., pp. 309-368.

Wilson, D., 1992. Sawdust Trails in the Truckee Basin: A History of Lumbering Operations Nevada County Historical Society, Nevada City, CA.

Yu, Z., Ito, E., 1999. Possible solar forcing of century-scale drought frequency in the northern Great Plains. Geology 27, 263-266.

Yuan, F., Linsley, B.K., Lund, S., McGeehin, J.P., 2004. A 1200 year record of hydrologic variability in the Sierra Nevada from sediments in Walker Lake. Nevada, Geochemistry Geophysics Geosystems 5, 1-13. 